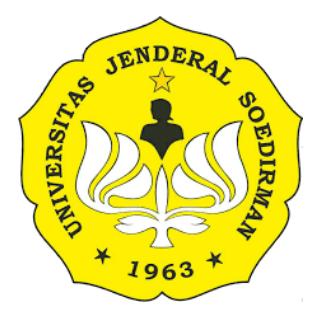

SOEDIRMAN ECONOMICS EDUCATION JOURNAL http://jos.unsoed.ac.id/index.php/seej/

\title{
PENGARUH POTENSI DIRI, LINGKUNGAN SEKOLAH DAN TINGKAT PENDIDIKAN ORANG TUA TERHADAP MINAT SISWA MELANJUTKAN STUDI KE PERGURUAN TINGGI DI MAN 1 BANYUMAS
}

\author{
Soli Solihat ${ }^{1}$, Titi Nurfitri ${ }^{2}$, Alisa Tri Nawarini ${ }^{3}$ \\ 1,2,3 Fakultas Ekonomi dan Bisnis, Universitas Jenderal Soedirman, Indonesia \\ Email corresponding author: solisolihatt19@gmail.com
}

\begin{abstract}
Abstrak
Penelitian ini merupakan penelitian dengan pendekatan deksriptif kuantitatif yang bertujuan untuk mengetahui pengaruh potensi diri, lingkungan sekolah dan tingkat pendidikan orang tua terhadap minat siswa melanjutkan studi ke perguruan tinggi siswa kelas XI MAN 1 Banyumas. Populasi penelitian ini adalah seluruh siswa kelas XI MAN 1 Banyumas sebanyak 345 siswa. Teknik pengambilan sampling yaitu simple randomsampling dengan jumlah sampel sebanyak 77 responden. Untuk menganalisis hipotesis menggunakanan anlisis regresi linier berganda. Kesimpulannya yaitu: 1 . Terdapat pengaruh positif potensi diri terhadap minat siswa XI MAN 1 Banyumas untuk melanjutkan studi ke perguruan tinggi; 2. Terdapat pengaruh positif lingkungan sekolah terhadap minat siswa XI MAN 1 Banyumas untuk melanjutkan studi ke perguruan tinggi; 3. Tidak terdapat pengaruh tingkat pendidikan orang tua terhadap minat siswa XI MAN 1 Banyumas untuk melanjutkan studi ke perguruan tinggi.
\end{abstract}

Kata Kunci: Potensi diri, Lingkungan sekolah, Tingkat pendidikan orang tua, Minat, Perguruan Tinggi.

\begin{abstract}
This research is a quantitative descriptive study that aims to determine the effect of the influence of selfpotential, school environment, and parents' education of the interest of the students to continue their studies to university students of class XI MAN 1 Banyumas. The population in this study were students of class XI MAN 1 Banyumas as many as 345 students. The sampling technique is simple random sampling with a total sample of 77 respondents. The hypothesis was analyzed by using multiple linear regression analysis. The conclusions were: 1 . The self-potential has a positive effect of the interest of the students XI MAN 1 Banyumas to continue their studies to university; 2. The school environment has a positive effect of the interest of the students XI MAN 1 Banyumas to continue their studies to university; 3. The parents' education no effect of the interest of the students XI MAN 1 Banyumas to continue their studies to university.
\end{abstract}

Keywords: Self-potential, School environment, Parents' education, Interest, University 


\section{PENDAHULUAN}

Di era globalisasi ini, persaingan dunia kerja semakin ketat, banyak lapangan pekerjaan yang membutuhkan tenaga kerja dengan status pendidikan tinggi dengan demikian, agar dapat lebih bersaing dan kompeten dalam dunia kerja, maka tidak cukup hanya mengeyam pendidikan sampai tingkat menengah atau sekolah dasar saja. Setelah menyelesaikan pendidikan di tingkat menengah, lulusan dapat meneruskan pendidikannya ke jenjang yang lebih tinggi. Lulusan sekolah menengah yang memilih untuk melanjutkan studi ke perguruan tinggi umumnya di dasari oleh minat yang tinggi. Slameto (2013) menyatakan bahwa minat adalah salah satu rasa lebih suka dan rasa ketertarikan pada suatu hal atau aktivitas yang dilakukan tanpa ada yang menyuruh.

Potensi diri siswa merupakan salah satu faktor yang mempengaruhi minat siswa dalam melanjutkan pendidikan keperguruan tinggi. Hasil penelitian Indriyanti (2013) menyatakan bahwa faktor yang paling besar mempengaruhi minat melanjutkan pendidikan ke perguruan tinggi pada siswa yaitu faktor potensi diri.

Faktor lingkungan sekolah merupakan situasi yang turut serta mempengaruhi minat siswa melanjutkan studi keperguruan tinggi. Penelitian yang dilakukan oleh Hartono (2016) menunjukan bahwa lingkungan sekolah berpengaruh positif terhadap terhadap minat melanjutkan studi ke perguruan tinggi. Faktor lain yang dapat mempengaruhi minat siswa untuk melanjutkan studi keperguruan tinggi yaitu tingkat pendidikan orang tua. Menurut Idris (2009) pengaruh tingkat pendidikan orang tua merupakan faktor utama dalam mendorong peserta didik untuk melanjutkan pendidikannya karena tingkat pendidikan orang tua sangat mempengaruhi kondisi pendidikan anak. Zaini (2015) dalam penelitiannya menunjukan bahwa tingkat pendidikan orang tua berpengaruh positif terhadap minat melanjutkan studi ke perguruan tinggi.

MAN 1 Banyumas adalah salah satu sekolah unggulan yang ada di Purwokerto berbasis keagamaan, dalam pelaksanaan pendidikannya lebih menitikberatkan kepada pengetahuan teoritis, sehingga siswa MA memang dibekali untuk melanjutkan ke perguruan tinggi bahkan dapat masuk pada perguruan tinggi islam dan perguruan tinggi umum. Sehingga seharusnya minat siswa MA lebih tinggi karena peluang untuk masuk perguruan tinggi lebih banyak. Berdasarkan pengamatan awal yang dilakukan di MAN 1 Banyumas, menunjukan bahwa minat siswa dalam melanjutkan ke perguruan tinggi berada dalam tingkatan yang rendah yang dilihat dari data jumlah siswa yang melanjutkan studi ke perguruan tinggi tabel 1.

Tabel 1. Data Jumlah Siswa yang melanjutkan ke Perguruan Tinggi

\begin{tabular}{|c|c|c|c|c|c|c|}
\hline No & $\begin{array}{c}\text { Tahun } \\
\text { pelajaran }\end{array}$ & $\begin{array}{c}\text { Jumlah } \\
\text { lulusan }\end{array}$ & $\begin{array}{c}\text { Melanj } \\
\text { utkan } \\
\text { ke PT }\end{array}$ & \% & $\begin{array}{c}\text { Tidak melanjutkan } \\
\text { dan tidak terdata }\end{array}$ & \% \\
\hline 1 & $2016 / 2017$ & 324 & 129 & 39,81 & 195 & 60,19 \\
\hline 2 & $2017 / 2018$ & 374 & 149 & 39,84 & 225 & 60,16 \\
\hline
\end{tabular}

Sumber: TU data kelulusan MAN 1 Banyumas 
Hasil wawancara yang dilakukan peneliti pula menunjukan bahwa sebagian siswa tidak berminat untuk melanjutkan studi ke perguruan tinggi dikarenakan ada beberapa faktor yang mempengaruhinya yaitu pertama karena masih banyaknya siswa yang belum menyadari potensi yang dimilikinya untuk bisa melanjutkan ke perguruan tinggi, kedua kendala ekonomi yang menyebabkan pandangan orang tua terhadap pentingnya pendidikan tinggi. Berdasarkan uraian di atas, peneliti akan melakukan penelitian tentang pengaruh potensi diri, lingkungan sekolah dan tingkat pendidikan orang tua terhadap minat siswa melanjutkan studi ke perguruan tinggi pada siswa kelas XI MAN 1 Banyumas.

\section{Tujuan Penelitian}

Tujuan penelitian ini adalah 1) Untuk menganalisis pengaruh potensi diri terhadap minat siswa kelas XI MAN 1 Banyumas melanjutkan studi ke perguruan tinggi; 2) Untuk menganalisis pengaruh lingkungan sekolah terhadap minat siswa kelas XI MAN 1 Banyumas melanjutkan studi ke perguruan tinggi; dan 3) Untuk menganalisis pengaruh tingkat pendidikan orang tua terhadap minat siswa kelas XI MAN 1 Banyumas melanjutkan studi ke perguruan tinggi.

\section{Ruang Lingkup Penelitian}

Agar tidak terjadi perbedaan pemahaman, maka penelitian dibatasi pada masalah-masalah sebagai berikut : 1) Potensi diri berkaitan dengan kecerdasan intelektual yang dapat dilihat dari prestasi siswa; 2) Lingkungan sekolah mencakup lingkungan sosial dan lingkungan akademis; 3) Tingkat pendidikan orang tua berkaitan dengan tingkat pendidikan formal terakhir yang di tempuh orang tua siswa.

\section{TINJAUAN PUSTAKA DAN PERUMUSAN HIPOTESIS}

\section{Minat Siswa untuk Melanjutkan Studi Keperguruan Tinggi}

Minat berkaitan dengan perasaan suka, senang, tertarik kepada suatu hal atau objek. Slameto (2013) menyatakan bahwa minat sebagai suatu rasa lebih suka dan rasa ketertarikan pada suatu hal atau aktivitas, tanpa ada yang menyuruh. Darmadi (2013) menyatakan bahwa minat adalah suatu keadaan di dimana seseorang memiliki perhatian yang mendalam terhadap sesuatu objek serta disertai keinginan untuk mengetahui dan mempelajari maupun membuktikannya lebih lanjut. Indiyanti (2013) mengatakan bahwa ada 7 faktor yang mempengaruhi minat anak melanjutkan pendidikan tinggi yaitu : (1) Faktor potensi diri, (2) motivasi, (3) Ekspetasi masa depan, (4) Peluang, (5) Lingkungan sosial, (6) Situasi dan kondisi, (7) Institusional. Slameto (2013:180) menyebutkan beberapa indikator minat yaitu: (1) Perasaan senang,(2) Keinginan siswa,(3) Perhatian siswa, (4) Ketertarikan Siswa. 


\section{Potensi Diri}

Habsari (2005) potensi diri adalah kemampuan dan kekuatan yang dimiliki oleh seseorang baik fisik maupun mental dan mempunyai kemungkinan untuk mengembangkan bila dilatih dan ditunjang dengan sarana yang baik. Menurut Wilyono (2006) mengemukakan bahwa potensi diri adalah kemampuam dasar yang dimiliki manusia yang masih terpendam dalam dirinya yang menunggu untuk diwujudkan menjadi sesuatu kekuatan nyata dalam kehidupan diri manusia Menurut Prihadhi (2004:6) potensi diri adalah suatu kekuatan yang masih terpendam yang berupa fisik, karakter, minat, bakat, kecerdasan dan nilai-nilai yang terkandung dalam diri tetapi belum dimanfaatkan dan diolah. Jenisjenis potensi diri : (1) Potensi otak/kecerdasan intelektual, (2) Potensi emosi/kecerdasan Emosional, (3) Potensi fisik/Kecerdasan fisik. Indikator potensi diri menurut Sugiharso (2009) yaitu : (1) Suka belajar dan mau melihat kekurangan dirinya, (2) Memiliki sikap yang luwes, (3) Berani melakukan perubahan untuk perbaikan, (4) Tidak mau menyalahkan orang lain maupun keadaan, (5) Memiliki sikap yang tulus bukan kelicikan, (6) Memiliki rasa tanggung jawab, (7) Menerima kritik saran dari luar, (8) Berjiwa optimis dan tidak mudah putus asa.

\section{Lingkungan sekolah}

Anshari (2004) lingkungan sekolah adalah segala sesuatu yang ada di sekitar anak, berupa baik benda-benda, peristiwa-peristiwa yang terjadi maupun kondisi masyarakat terutama yang dapat memberikan pengaruh kuat kepada anak, yaitu lingkungan dimana proses pendidikan berlangsung dan lingkungan dimana anak-anak bergaul sehari-harinya. Sukmadinata (2004) menjelaskan lingkungan sekolah meliputi: (1) Lingkungan fisik sekolah seperti sarana dan prasarana belajar, sumber-sumber belajar,dan media belajar, (2) Lingkungan sosial sekolah menyangkut hubungan siswa dengan temantemanya, guru-gurunya, dan staf sekolah yang lain, (3) Lingkungan Akademis yaitu suasana sekolah dan pelaksanaan kegiatan belajar mengajar dan berbagai kegiatan kokurikuler.

\section{Tingkat Pendidikan Orang Tua}

Ihsan (2003) pendidikan dapat diartikan sebagai suatu proses pertumbuhan yang menyesuaikan dengan lingkungan, suatu pengarahan dan bimbingan yang diberikan kepada anak dalam pertumbuhannya, suatu usaha sadar untuk menciptakan suatu keadaan atau situasi tertentu yang dikehendaki oleh masyarakat dan suatu pembentukan kepribadian dan kemampuan anak dalam menuju kedewasaan. Menurut Ihsan (2003) tingkat atau jenjang pendidikan adalah tahap pendidikan yang berkelanjutan yang ditetapkan berdasarkan tingkat perkembangan peserta didik, tingkat kerumitan bahan pengajaran dan cara menyajikan bahan pengajaran.

Menurut Undang- Undang No. 20 Tahun 2003 Pasal 17 tentang Sistem Pendidikan Nasional jenjang pendidikan sekolah terdiri dari: (1) Pendidikan dasar merupakan jenjang pendidikan yang melandasi jenjang pendidikan menengah. Pendidikan dasar berbentuk Sekolah Dasar (SD) dan 
Madrasah Ibtidaiyah (MI) atau bentuk lain yang sederajat serta Sekolah Menengah Pertama (SMP) dan Madrasah Tsanawiyah (MTs), atau bentuk lain yang sederajat, (2) Pendidikan menengah merupakan lanjutan pendidikan dasar. Pendidikan menengah terdiri atas pendidikan menengah umum dan pendidikan menengah kejuruan. Pendidikan menengah berbentuk Sekolah Menengah Atas (SMA), Madrasah Aliyah (MA), Sekolah Menengah Kejuruan (SMK), dan Madrasah Aliyah Kejuruan (MAK), atau bentuk lain yang sederajat, (3) Pendidikan tinggi merupakan jenjang pendidikan setelah pendidikan menengah yang mencakup program pendidikan diploma, sarjana, magister, spesialis, dan doktor yang diselenggarakan oleh pendidikan tinggi. Perguruan Tinggi dapat berbentuk akademi, politeknik, sekolah tinggi, institut, atau universitas.

\section{Perumusan Hipotesis}

\section{Pengaruh Potensi Diri terhadap Minat Melanjutkan Studi ke Perguruan Tinggi}

Habsari (2005) mengemukakan bahwa potensi diri adalah kemampuan dan kekuatan yang dimiliki oleh seseorang baik fisik maupun mental dan mempunyai kemungkinan untuk mengembangkan bila dilatih dan ditunjang dengan sarana yang baik. Selain itu penelitian yang dilakukan oleh Indriyanti (2013) menyatakan bahwa potensi diri merupakan faktor yang paling besar mempengaruhi minat siswa untuk melanjutkan studi ke perguruan tinggi.

Hasil penelitian yang dilakukan oleh Armelia (2017) membuktikan bahwa potensi diri berpengaruh positif terhadap minat siswa melanjutkan studi ke perguruan tinggi. Selanjutnya penelitian yang dilakukan oleh Maita (2017) menunjukan bahwa potensi diri berpengaruh signifikan terhadap minat siswa melanjutkan studi ke perguruan tinggi Berdasarkan telaah pustaka dan hasil penelitian di atas, maka dapat dirumuskan hipotesis penelitian ini yaitu: $\mathrm{H}_{1}$ : Potensi Diri berpengaruh positif terhadap minat melanjutkan studi ke perguruan tinggi

\section{Pengaruh Lingkungan sekolah terhadap Minat Melanjutkan Studi ke Perguruan Tinggi}

Tu'u (2004) mengemukakan bahwa lingkungan sekolah adalah lembaga pendidikan formal dimana di tempat ini kegiatan pembelajaran berlangsung, ilmu pengetahuan diajarkan dan dikembangkan kepada anak didik. Menurut Indrawati (2013) lingkungan sekolah merupakan situasi yang turut serta mempengaruhi minat siswa melanjutkan studi keperguruan tinggi. Hal ini diperkuat oleh Hartono (2016) dalam penelitiannya menunjukan bahwa ada pengaruh positif lingkungan sekolah terhadap minat siswa melanjutkan studi keperguruan tinggi. Penelitian lain yang dilakukan oleh Khadijah (2017) menunjukan lingkungan sekolah berpengaruh positif terhadap minat siswa melanjutkan studi ke perguruan tinggi $\mathrm{H}_{2}$ : Lingkungan Sekolah berpengaruh positif terhadap minat melanjutkan studi ke perguruan tinggi. 


\section{Pengaruh Tingkat Pendidikan Orang Tua terhadap Minat Melanjutkan Studi ke Perguruan Tinggi}

Indriyanti (2013) salah satu faktor yang mempengaruhi minat siswa untuk melanjutkan studi ke perguruan tinggi adalah faktor situasi dan kondisi yang mewakili variabel keluarga dengan salah satu indikator yaitu tingkat pendidikan orang tua. Ihsan (2003) mengemukakan bahwa tingkat pendidikan orang tua adalah tahap pendidikan yang ditetapkan berdasarkan tingkat perkembangan peserta didik, tingkat kerumitan bahan pengajaran dan cara menyajikan bahan pengajaran. Menurut Kamus Besar Bahasa Indonesia tingkat pendidikan adalah jenjang pendidikan Indonesia yang dialami dalam suatu lembaga formal maupun informal. Menurut Idris (2009) pengaruh tingkat pendidikan orang tua merupakan faktor utama dalam mendorong peserta didik untuk melanjutkan studi ke perguruan tinggi. Hal ini di perkuat oleh penelitian Fiolina (2016) bahwa tingkat pendidikan orang tua berpengaruh positif terhadap minat siswa melanjutkan studi ke perguruan tinggi. Penelitian lain yang dilakukan oleh Mella (2009) menunjukan bahwa tingkat pendidikan orang tua berpengaruh secara signifikan terhadap minat siswa melanjutkan studi ke perguruan tinggi.

$\mathrm{H}_{3}$ : Tingkat pendidikan orang tua berpengaruh positif terhadap minat siswa melanjutkan studi ke perguruan tinggi.

\section{Model Penelitian}

Berdasarkan hasil penelitian terdahulu dan pengembangan hipotesis maka peneliti ingin mengetahui pengaruh antar variabel. Pengaruh antar variabel tersebut diantaranya adalah pengaruh potensi diri terhadap minat siswa melanjutkan studi ke perguruan tinggi, pengaruh lingkungan sekolah terhadap minat siswa melanjutkan studi ke perguruan tinggi, dan pengaruh tingkat pendidikan orang tua terhadap minat siswa melanjutkan studi ke perguruan tinggi. Model penelitian dalam penelitian ini dapat dilihat pada gambar 1 .

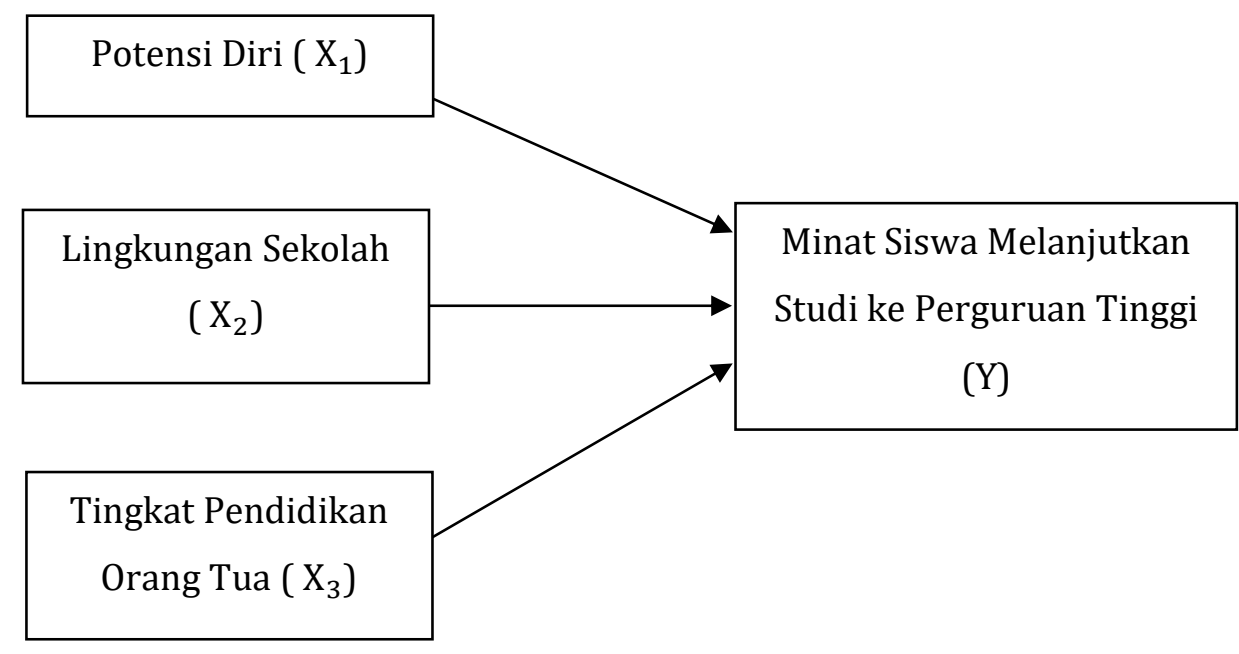

Gambar 1. Model Penelitian 


\section{METODE PENELITIAN}

Jenis penelitian yang digunakan adalah penelitian kuantitatif deskriftif, dengan menggunakan instrumen kuesioner. Penelitian ini dilaksanakan di MAN 1 Banyumas. Subjek penelitian ini adalah siswa kelas XI MAN 1 Banyumas. Objek penelitian ini adalah minat melanjutkan studi yang dipengaruhi oleh potensi diri, lingkungan sekolah dan tingkat pendidikan orang tua.

Populasi dalam penelitian ini adalah keseluruhan siswa kelas XI MAN 1 Banyumas sebanyak 345 siswa. Sedangkan sampel dalam penelitian ini adalah siswa kelas XI IPA 1, XI IPS 2, dan XI Agama 2 sebanyak 77 siswa.

Jenis data yang digunakan berupa data primer dan data sekunder. Dalam memperoleh data untuk penelitian ini penulis menggunakan teknik kuesioner, wawancara dan dokumentasi, yang digunakan untuk mendapatkan informasi terkait variabel yang digunakan yakni potensi diri, lingkungan sekolah dan tingkat pendidikan orang tua. Uji instrumen terdiri dari uji instrumen kuesioner. Instrumen diuji coba untuk mengetahui validitas, reliabilitas, dengan menggunakan skala likert 1-5. Sebelum dilakukan uji analisis data, maka data penelitian harus dilakukan uji asumsi klasik terlebih dahulu, dalam penelitian ini uji asumsi klasik meliputi uji normalitas, uji multikolinieritas, dan uji heteroskedastistas. Analisis data menggunakan uji koefisien determinasi, uji t, uji f, dan analisis regresi linier berganda yang dilakukan menggunakan SPSS 23.

\section{HASIL DAN PEMBAHASAN}

Penelitian ini menganalisis mengenai pengaruh potensi diri, lingkungan sekolah dan tingkat pendidikan orang tua terhadap minat siswa melanjutkan studi ke perguruan tinggi di MAN 1 Banyumas. Jumlah kuesioner yang dibagikan sebanya 77 siswa sebagai responden Kuesioner penelitian ini diberikan langsung kepada responden dan ditunggu sampai pengisian selesai karena untuk memastikan pengisian kuesioner dan kembali sesuai dengan jumlah kuesioner yang dibagikan. Pada pembagian kuesioner kepada responden di setiap kelas yang telah ditentukan oleh peneliti dilakukan pada saat jam istirahat atau sedang tidak ada proses pembelajaran, sehingga tidak mengganggu proses pembelajaran. Peneliti menggunakan data primer dan data sekunder.

Data primer diperoleh secara langsung melalui kusioner terkait variabel yang digunakan dalam penlitian ini, yaitu minat siswa melanjutkan studi ke perguruan tinggi, potensi diri, lingkungan sekolah dan tingkat pendidikan orang tua dan yang diisi oleh siswa sebagai respnden. Variabel ini minat siswa melanjutkan studi ke perguruan tinggi terdiri dari 4 indikator yang dijabarkan menjadi 11 pernyataan. Jawaban responden dapat dilihat dari tabel 2. 
Tabel 2. Jawaban Responden minat siswa melanjutkan studi ke perguruan tinggi

\begin{tabular}{|c|c|c|c|c|}
\hline Kriteria Index dalam \% & Alternatif Jawaban & $\begin{array}{c}\text { Skor } \\
\text { (1) }\end{array}$ & $\begin{array}{c}\text { Frekuensi } \\
\mathbf{( 2 )}\end{array}$ & $\begin{array}{c}\text { Jumlah } \\
\text { (1) x (2) }\end{array}$ \\
\hline $81-100$ & Sangat Setuju & 5 & 488 & 2440 \\
\hline $61-80$ & Setuju & 4 & 315 & 1260 \\
\hline $41-60$ & Netral & 3 & 10 & 30 \\
\hline $21-40$ & Tidak Setuju & 2 & 30 & 60 \\
\hline $1-20$ & Sangat Tidak Setuju & 1 & 4 & 4 \\
\hline & & & 847 & 3794 \\
\hline
\end{tabular}

Jawaban responden terkait variabel potensi diri yang dihitung menggunakan rumus index \% yaitu sebesar 89,58\% yang termasuk dalam kategori sangat setuju. Berdasarkan hasil kuesioner tersebut, diketahui bahwa mayoritas responden memiliki minat yang tinggi untuk melanjutkan studi ke perguruan tinggi.

Variabel potensi diri terdiri dari 8 indikator yang dirumuskan menjadi 16 pernyataan. Jawaban responden bisa dilihat pada tabel 3 .

Tabel 3. Jawaban Responden Potensi Diri

\begin{tabular}{|c|c|c|c|c|}
\hline Kriteria Index dalam \% & Alternatif Jawaban & $\begin{array}{c}\text { Skor } \\
\text { (1) }\end{array}$ & $\begin{array}{c}\text { Frekuensi } \\
\mathbf{( 2 )}\end{array}$ & $\begin{array}{c}\text { Jumlah } \\
\text { (1) x (2) }\end{array}$ \\
\hline $81-100$ & Sangat Setuju & 5 & 672 & 3360 \\
\hline $61-80$ & Setuju & 4 & 549 & 2196 \\
\hline $41-60$ & Netral & 3 & 13 & 39 \\
\hline $21-40$ & Tidak Setuju & 2 & 0 & 0 \\
\hline $1-20$ & Sangat Tidak Setuju & 1 & 0 & 0 \\
\hline & & & 1234 & 5595 \\
\hline
\end{tabular}

Jawaban responden terkait variabel potensi diri yang dihitung menggunakan rumus index \% yaitu sebesar 90,82\% yang termasuk dalam kategori sangat setuju. Berdasarkan hasil kuesioner tersebut, diketahui bahwa sebagian besar responden mempunyai bakat yang mendorong untuk melanjutkan studi ke perguruan tinggi.

Variabel lingkungan sekolah ini terdiri dari 2 indikator yang dijabarkan menjadi 8 pernyataan. Jawaban responden bisa dilihat pada tabel 19.

Tabel 4. Jawaban Responden Lingkungan Sekolah

\begin{tabular}{|c|c|c|c|c|}
\hline Kriteria Index dalam \% & Alternatif Jawaban & $\begin{array}{c}\text { Skor } \\
\text { (1) }\end{array}$ & $\begin{array}{c}\text { Frekuensi } \\
\text { (2) }\end{array}$ & $\begin{array}{c}\text { Jumlah } \\
\text { (1) x (2) }\end{array}$ \\
\hline $81-100$ & Sangat Setuju & 5 & 220 & 1100 \\
\hline $61-80$ & Setuju & 4 & 395 & 1580 \\
\hline $41-60$ & Netral & 3 & 0 & 0 \\
\hline $21-40$ & Tidak Setuju & 2 & 1 & 2 \\
\hline $1-20$ & Sangat Tidak Setuju & 1 & 0 & 0 \\
\hline & & & 616 & 2682 \\
\hline
\end{tabular}


Jawaban responden terkait variabel lingkungan sekolah yang dihitung menggunakan rumus index \% yaitu sebesar 87,07\% yang termasuk dalam kategori setuju. Berdasarkan hasil kuesioner tersebut bahwa sebagian besar responden menilai lingkungan sekolah sudah menunjang dan membantu siswa untuk melanjutkan studi ke perguruan tinggi.

Variabel tingkat pendidikan orang tua terdiri dari 2 indikator yang dijabarkan menjadi 2 pertanyaan.

Tabel 5. Distribusi Frekuensi Tingkat Pendidikan Orang Tua

\begin{tabular}{|c|c|c|c|c|}
\hline \multirow{2}{*}{ No } & \multirow{2}{*}{ Skor } & \multicolumn{3}{|c|}{ Frekuensi } \\
\cline { 3 - 5 } & & Absolut & Relatif (\%) & Komulatif(\%) \\
\hline 1 & $6-7$ & 24 & 31,2 & 31,2 \\
\hline 2 & $8-9$ & 10 & 13 & 44,2 \\
\hline 3 & $10-11$ & 11 & 14,3 & 58,5 \\
\hline 4 & $12-13$ & 13 & 16,9 & 75,4 \\
\hline 5 & $14-15$ & 10 & 13 & 88,4 \\
\hline 6 & $16-17$ & 8 & 10,4 & 98,8 \\
\hline 7 & $18-19$ & 1 & 1,2 & 100 \\
\hline & Total & 77 & 100 & \\
\hline
\end{tabular}

Tabel 6. Kategori Kecenderungan Variabel Tingkat Pendidikan Orang Tua

\begin{tabular}{|l|l|l|l|l|l|}
\hline \multirow{2}{*}{ No } & \multirow{2}{*}{ Skor } & \multicolumn{3}{|c|}{ Frekuensi } & \multirow{2}{*}{ Kategori } \\
\cline { 3 - 5 } & & Absolute & Relatif \% & Komulatif & \\
\hline 1 & $\mathrm{X}>14$ & 19 & 24,6 & 24,6 & Sangat tinggi \\
\hline 2 & $12 \leq \mathrm{X} \leq 14$ & 13 & 16,8 & 41,4 & Tinggi \\
\hline 3 & $10 \leq \mathrm{X}<12$ & 11 & 14,4 & 55,8 & Sedang \\
\hline 4 & $\mathrm{X}<10$ & 34 & 44,2 & 100 & Rendah \\
\hline & Total & 77 & 100 & & \\
\hline
\end{tabular}

Berdasarkan tabel di atas dapat diketahui bahwa kecenderungan tingkat pendidikan orang tua pada siswa kelas XI MAN 1 Banyumas berada pada kategori rendah karena frekuensi terbanyak yaitu 34 siswa berada pada skor $\mathrm{X}<10$.

Selanjutnya dilakukan uji normalitas, multikolinieritas, dan heteroskedastisitas. Berdasarkan hasil uji normalitas sebesar 0,059 > 0,05 menunjukkan bahwa data yang diuji berdistribusi normal. Hasil uji multikolinieritas semua variabel yaitu : nilai tolerance untuk variabel potensi diri sebesar 0,804, lingkungan sekolah sebesar 0,803 dan tingkat pendidikan orang tua sebesar 0,995 menunjukan nilai tolerance $>$ 0,1 dan nilai VIF untuk variabel potensi diri sebesar 1,243, lingkungan sekolah sebesar 1,245 dan tingkat pendidikan orang tua sebesar 1,005 menunjukan nilai VIF $<10$, maka dapat disimpulkan bahwa antara variabel bebas tidak terjadi multikolinearitas. Sedangkan hasil uji heteroskedastisitas menunjukkan tidak terjadi heteroskedastisitas karena nilai signifikansi semua variabel lebih dari 0,05. Semua data tersebut memenuhi syarat untuk dilakukan uji selanjutnya. Pengujian hipotesis menggunakan uji t dan analisis regresi berganda. 
Berdasarkan hasil perhitungan analisis regresi dengan menggunakan bantuan program IBM SPSS 23 diperoleh persamaan regresi $Y=-2,238+0,251 X_{1}+0,902 X_{2}+0,018 X_{3}$. Dari persamaan regresi linear berganda dapat dijabarkan sebagai berikut : (1) Konstanta sebesar -2,238 hal tersebut mengindikasikan ketika variabel potensi diri, lingkungan sekolah dan tingkat pendidikan orang tua tidak mengalami perubahan, maka minat siswa melanjutkan studi ke perguruan tinggi diprediksi akan menurun. (2) Koefisien regresi variabel potensi diri sebesar 0,251, nilai koefisien regresi yang positif. Hal ini membuktikan pengaruh positif antara potensi diri dengan minat siswa melanjutkan studi ke perguruan tinggi, yang berarti bahwa semakin tinggi potensi diri yang dimiliki siswa, maka minat siswa untuk melanjutkan studi ke perguruan tinggi akan semakin tinggi atau meningkat. (3) Koefisien regresi variabel lingkungan sekolah sebesar 0,902 , nilai koefisien regresi yang positif. Hal ini menunjukan adanya pengaruh positif antara lingkungan sekolah dengan minat melanjutkan studi ke perguruan tinggi, yang berarti bahwa ketika lingkungan sekolah memadai, mendukung, dan menunjang untuk dapat melanjutkan studi ke perguruan tinggi, maka minat siswa untuk melanjutkan studi ke perguruan tinggi semakin tinggi atau meningkat. (4) Koefisien regresi variabel tingkat pendidikan orang tua sebesar 0,018 , nilai koefisien regresi yang positif. Hal ini menunjukan adanya pengaruh positif antara tingkat pendidikan orang tua siswa dengan minat siswa melanjutkan studi ke perguruan tinggi, yang berarti bahwa semakin tinggi tingkat pendidikan orang tua maka minat siswa untuk melanjutkan studi ke perguruan tinggi semakin tinggi atau meningkat.

Hasil koefisien determinasi nilai adjusted $\mathrm{R}$ square sebesar 0,572 ini mengartikan bahwa sumbangan variabel potensi diri (X1), lingkungan sekolah (X2), dan tingkat pendidikan orang tua (X3) terhadap minat siswa melanjutkan studi ke perguruan tinggi (Y) memiliki nilai sebesar 57,2\% sedangkan untuk 42,8 \% tidak dipengaruhi oleh variabel yang diteliti atau faktot lain yang tidak diteliti dalam penelitian ini.

Hasil ANOVA diperoleh $\mathrm{F}$ hitung sebesar 32,681, sedangkan $\mathrm{F}$ tabel dengan derajat kebebasan : $\mathrm{df}=(\mathrm{k}, \mathrm{n}-\mathrm{k})=(3,72-3)=(3,69)$, diperoleh hasil $\mathrm{F}$ tabel sebesar 2,74. Maka diketahui nilai $\mathrm{F}$ hitung $>\mathrm{F}$ tabel yaitu 32,681 > 2,74 dan nilai signifikansi $<0,05$ yaitu 0,000 $<0,05$ menunjukan bahwa potensi diri, lingkungan sekolah dan tingkat pendidikan orang tua secara simultan berpengaruh terhadap minat siswa melanjutkan studi ke perguruan tinggi dan dapat disimpulkan pula bahwa potensi diri, lingkungan sekolah dan tingkat pendidikan orang tua sudah termasuk kategori fit

Hasil $t$ untuk variabel potensi diri diperoleh nilai t hitung sebesar 3,211 sedangkan $t$ tabel dengan derajat keabsahan $:(\alpha / 2, \mathrm{n}-\mathrm{k}-1)=(0,05 / 2 ; 72-3-1)=(0.025 ; 68)=1,995$ ini menunjukan $\mathrm{t}$ hitung $>\mathrm{t}$ tabel dan diketahui nilai signifikansi 0,002 $<0,05$ maka dapat diambil kesimpulan Ho ditolak Ha diterima yang artinya variabel potensi diri secara parsial berpengaruh positif terhadap minat siswa melanjutkan studi ke perguruan tinggi.

Hasil t untuk variabel lingkungan sekolah diperoleh nilai t hitung sebesar 6,955 sedangkan $t$ tabel dengan derajat keabsahan : $(\alpha / 2, \mathrm{n}-\mathrm{k}-1)=(0,05 / 2 ; 72-3-1)=(0.025 ; 68)=1,995$ ini menunjukan 
thitung $>$ t tabel dan diketahui nilai signifikansi 0,000 $<0,05$ maka dapat diambil kesimpulan Ho ditolak Ha diterima yang artinya variabel lingkungan sekolah secara parsial berpengaruh positif terhadap minat siswa melanjutkan studi ke perguruan tinggi.

Hasil t untuk variabel tingkat pendidikan orang tua diperoleh nilai $t$ hitung sebesar 0,274 sedangkan $t$ tabel dengan derajat keabsahan $:(\alpha / 2, n-k-1)=(0,05 / 2 ; 72-3-1)=(0.025 ; 68)=1,995$ ini menunjukan $\mathrm{t}$ hitung $<\mathrm{t}$ tabel dan diketahui nilai signifikansi $0,000<0,05$ maka dapat diambil kesimpulan Ho diterima Ha ditolak yang artinya variabel tingkat pendidikan orang tua secara parsial tidak berpengaruh terhadap minat siswa melanjutkan studi ke perguruan tinggi.

\section{KESIMPULAN}

Mengacu pada kesimpulan dan analisis data, maka dapat disimpulkan bahwa: (1) Potensi diri berpengaruh positif terhadap minat siswa melanjutkan studi ke perguruan tinggi. Adanya pengaruh tersebut menunjukan bahwa semakin tinggi potensi diri siswa maka semakin meningkat pula minat siswa untuk melanjutkan studi ke perguruan tinggi. (2) Lingkungan sekolah berpengaruh positif terhadap minat siswa melanjutkan studi ke perguruan tinggi. Adanya pengaruh tersebut menunjukan bahwa lingkungan sekolah memadai, menunjang, dan mendukung untuk masuk ke perguruan tinggi maka minat siswa untuk melanjutkan studi ke perguruan tinggi akan tinggi atau meningkat (3) Tingkat pendidikan orang tua tidak berpengaruh terhadap minat siswa. Siswa yang mempunyai orang tua yang berpendidikan tinggi tidak berarti siswa tersebut minat untuk melanjutkan studi ke perguruan tinggi, begitu pula siswa yang mempunyai orang tua yang berpendidikan rendah tidak berarti siswa tersebut tidak minat untuk melanjutkan studi ke perguruan tinggi.

\section{DAFTAR PUSTAKA}

Armelia. (2017). Pengaruh Pendapatan Orang Tua, Lingkungan Sosial Sekolah dan Potensi Diri Terhadap Minat Siswa Melanjutkan Studi Kperguruan Tinggi Pada Siswa Kelas XII IPS SMA Al Istiqamah Kabupaten Pasaman Barat. Jurnal pendidikan. Pendidikan Ekonomi Sekolah Tinggi Keguruan Ilmu Pendidikan (STKIP) PGRI Sumatera Barat. (Diakses 15 Januari 2019).

Darmadi. (2013). Pengembangan Model dan Metode Pembelajaran dalam Dinamika Belajar Siswa. Yogyakarta: Deepublish.

Fiolina. (2016). Pengaruh Pendapatan dan Pendidikan Orangtua Terhadap Minat Melanjutkan Studi ke Perguruan Tinggi Siswa Kelas XII SMA Negeri 1 Siantar Narumonda Tahun Ajaran 2016/2017. Skripsi, Jurusan Pendidikan Geografi, Fakultas Ilmu Sosial, Universitas Negeri Medan.

Habsari. (2005). Bimbingan \& Konseling SMA kelas XI. Jakarta:Grasindo

Hartono. (2016). Pengaruh lingkungan sekolah dan konsep diri terhadap minat melanjutkan ke perguruan tinggi pada siswa kelas XII SMA/Sederajat di Kecamatan Kadugede Kabupaten Kuningan. (Diakses 15 Januari 2019).

Ihsan. (2005). Dasar Kependidikan. Jakarta: PT Rineka Cipta. 
Indriyanti, Ninuk. 2013. Faktor-faktor yang Mempengaruhi Minat Melanjutkan Pendidikan Ke Perguruan Tinggi Pada Siswa Kelas XII Akuntansi SMK Negeri 6 Surakarta Tahun 2013. Jupe UNS, Vol 1, No. 2, hal 1-10.

Khadijah, Siti. 2017. Analisis Minat Peserta Didik untuk Melanjutkan Pendidikan Tinggi. Jurnal pendidikan Ilmu Sosial. Volume 26, Nomor 2, Desember. Lembaga pendidikan Universitas Pendidikan.

Maita. 2017. Pengaruh Potensi Diri, Motivasi Siswa, dan Pendapatan Orang Tua terhadap Minat Siswa Kelas XII SMK Negeri 2 Gunung Talung untuk Melanjutkan Pendidikan ke Perguruan Tinggi.

Prihadhi. 2004. My Potensi. Jakarta: Elek Media Komputindo.

Slameto. 2013. Belajar dan Faktor-Faktor yang Mempengaruhi. Jakarta: PT. Rineka Cipta.

Sukmadinata. 2004. Landasan Psikologi Proses Pendidikan. Bandung: Rosda.

Tu’u. 2004. Peran Disiplin Pada Prilaku dan Prestasi Siswa. Jakarta: Graasindo.

Undang- Undang No. 20 tahun 2003. Sistem Pendidikan Nasional.

Wilyono, Slamet. 2006. Managemen Potensi Diri. Jakarta. PT Grasindo.

Zaini, Ahmad. Pengaruh Status Sosial Ekonomi dan Tingkat Pendidikan Orang Tua Terhadap Minat Studi Lanjut Siswa Kelas XII di Ma Miftahul Huda Cendono Purwosari Kabupaten Pasuruan. 